\title{
Microbial fuel cell: a green approach for the utilization of waste for the generation of bioelectricity
}

\author{
Venkatesh Chaturvedi ${ }^{1}$ and Pradeep Verma $2^{2^{*}}$
}

\begin{abstract}
Today we are witnessing a global energy crisis due to huge energy demands and limited resources. Non-renewable energy sources are depleting and renewable energy sources are not properly utilized. There is an immediate need for search of alternate routes for energy generation. Microbial fuel cell (MFC) technology, which uses microorganisms to transform chemical energy of organic compounds into electricity is considered a promising alternative. Extensive studies have corroborated new insights into MFC, which show that a wide array of carbon sources including wastes can be employed using a variety of microbes. Consequently, microbial transformation of wastes using novel bioremediation strategies such as MFC for energy generation is considered as an efficient and environmentally benign approach. This paper deals with critical review of different classes of xenobiotics and wastes that can be employed for bioenergy generation, microorganisms involved, power output, major benefits, challenges and pit holes of MFC technology.
\end{abstract}

Keywords: Microbial fuel cell (MFC), Electricity, Technology, Waste, Pollutant, Xenobiotic

\section{Background}

Energy requirement is ever increasing throughout the world. In this regard, fossil fuels have catered to a major portion of the total energy requirement, in one way or another. This has subsequently resulted in tremendous depletion of fossil fuel resources and is bringing about an ecological imbalance. In addition, combustion of fossil fuels generates a lot of carbon dioxide, which is a major green house gas and has shown alarming consequences on the environment. Therefore, search for alternate sources of energy generation that are cheap and ecofriendly have become a prime necessity (Logan 2004). Microbial fuel cells (MFC) technology, which harnesses energy from metabolism of microorganisms, seems to be attractive to warrant energy generation (Logan 2004; Rabaey et al. 2003; Venkata Mohan et al. 2008) (Fig. 1). The use of MFC as an alternative source for power generation is considered as a reliable, clean, efficient process,

\footnotetext{
*Correspondence: vermaprad@yahoo.com

${ }^{2}$ Department of Microbiology, Central University of Rajasthan, N.H. 8

Bandarsindri, Kishangarh, Ajmer 305801, Rajasthan, India

Full list of author information is available at the end of the article
}

which utilizes renewable methods and does not generate any toxic by-product. Therefore, in recent years, MFCs have shown to be a potent technology for recovery and in situ conversion of chemical energy into electricity (Logan 2004).

An MFC is a system in which microbes convert chemical energy produced by the oxidation of organic/inorganic compounds into ATP by sequential reactions in which electrons are transferred to a terminal electron acceptor to generate an electrical current (Torres et al. 2009). A typical MFC consists of anode and cathode compartments, which are separated by a cationic membrane. Microbes reside in the anode compartment, where they metabolize organic compounds such as glucose which act as electron donor. The metabolism of these organic compounds generates electrons and protons. Electrons are then transferred to the anode surface. From anode, the electrons move to cathode through the electrical circuit, while the protons migrate through the electrolyte and then through the cationic membrane. Electrons and protons are consumed in the cathode by reduction of soluble electron acceptor, such as oxygen or hexacynoferrate 


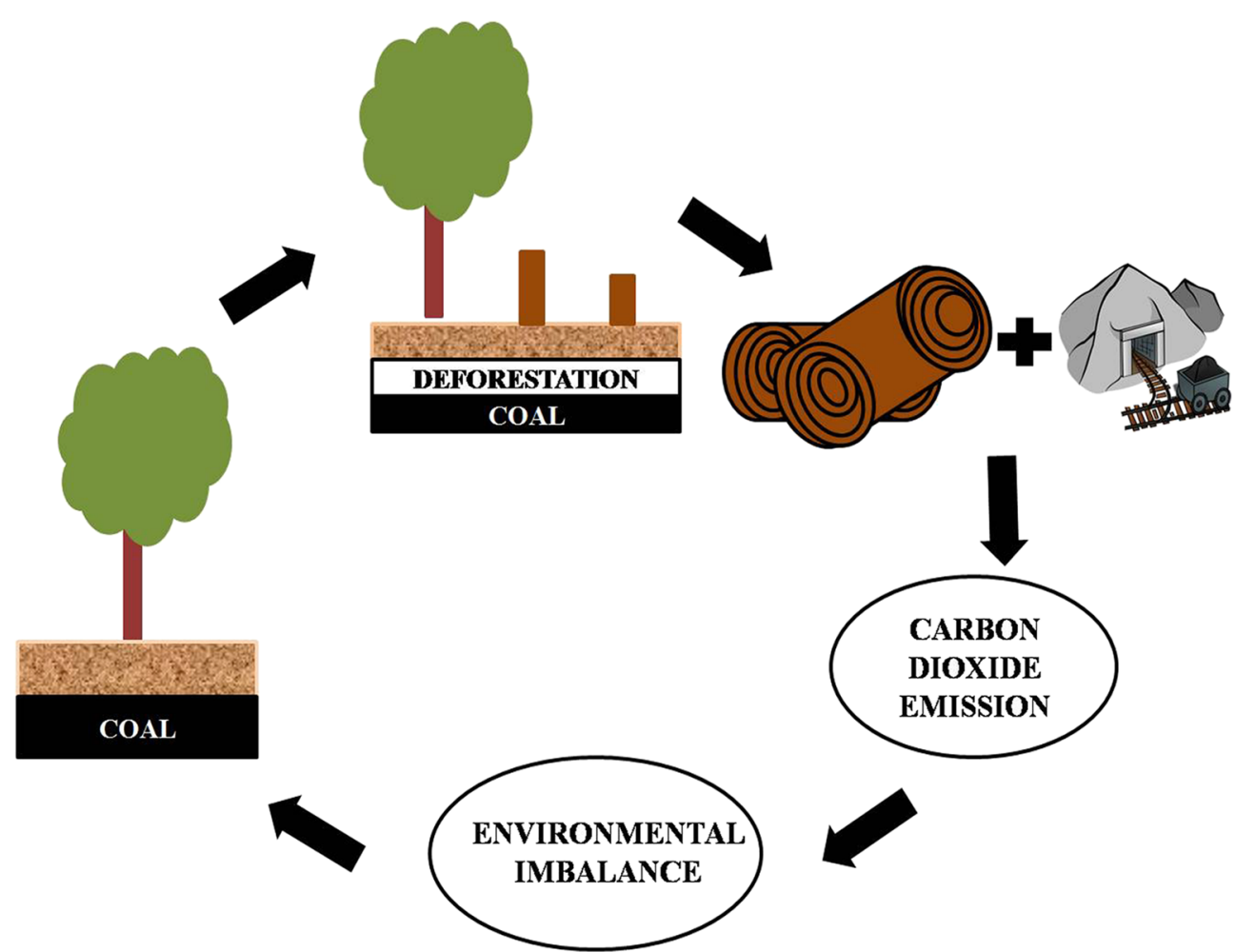

Fig. 1 Schematic diagram showing reasons for the increase in demand for energy requirement, resulting in depletion of non-renewable energy resources

(Rabaey et al. 2004) and acidic permanganate (You et al. 2006). Electrical power is harnessed by placing a load between the two electrode compartments (Allen and Bennetto 1993) (Fig. 2). However, the use of oxygen could avoid the potential environmental pollution resulted from the use of liquid-state electron acceptors. To accelerate the oxygen reduction on the surface of the cathode, platinum is commonly used because of its excellent catalytic ability. However, the high cost of platinum is a major limitation to MFC application and economic viability. Replacement of platinum with alternative cheap metals, such as manganese dioxide ( $\mathrm{Li}$ et al. 2010), iron(II) and cobalt-based materials (Cheng et al. 2006a, b; Ter Heijne et al. 2007), could also improve the oxygen reduction rate with cost saving. Metal-based materials, however, are generally susceptible to the adverse environmental conditions that may occur in MFCs and cause inactivation (Sun et al. 2011a, b). Recent development of biocathode that uses microorganisms as catalysts to assist electron transfer is a promising way to improve cathode performance without the use of noble metal. Many compounds other than oxygen could be also used as terminal electron acceptors in biocathode, such as nitrate, sulfate, iron, manganese, selenate, arsenate, urinate, fumarate, carbon dioxide and hexavalent chromium (Stams et al. 2006;
Wang et al. 2008). This provides a potential approach for wastewater treatment using biocathode due to its variety of terminal electron acceptors such as recalcitrant wastes like azo dyes (Sun et al. 2011a, b).

On the basis of design, MFC can be divided into two main types: single chambered and dual chambered. The MFC described above containing separate cathodic and anodic chambers is called dual-chambered MFC, whereas, the one which contains both cathode and anode in a single chamber is single-chambered MFC (Fig. 3a, b).

A wide variety of substrates have been employed in MFC. The substrates not only influence the integral composition of the bacterial community in the anode biofilm, but also the MFC performance including the power density (PD) and Coulombic efficiency (CE) (Chae et al. 2009). During development of this technology, low molecular weight substrates were employed as substrates, i.e., carbohydrates such as glucose, fructose, xylose, sucrose, maltose and trehalose (Chaudhuri and Lovley 2003; Kim et al. 2000a, b), organic acids such as acetate, propionate, butyrate, lactate, succinate and malate (Bond and Lovley 2005; Holmes et al. 2004a, b; Min and Logan 2004), alcohols such as ethanol and methanol (Kim et al. 2007) and inorganic compounds such as sulfate (Rabaey et al. 2006). Later, complex substrates such as starch, cellulose, dextran, molasses, chitin 


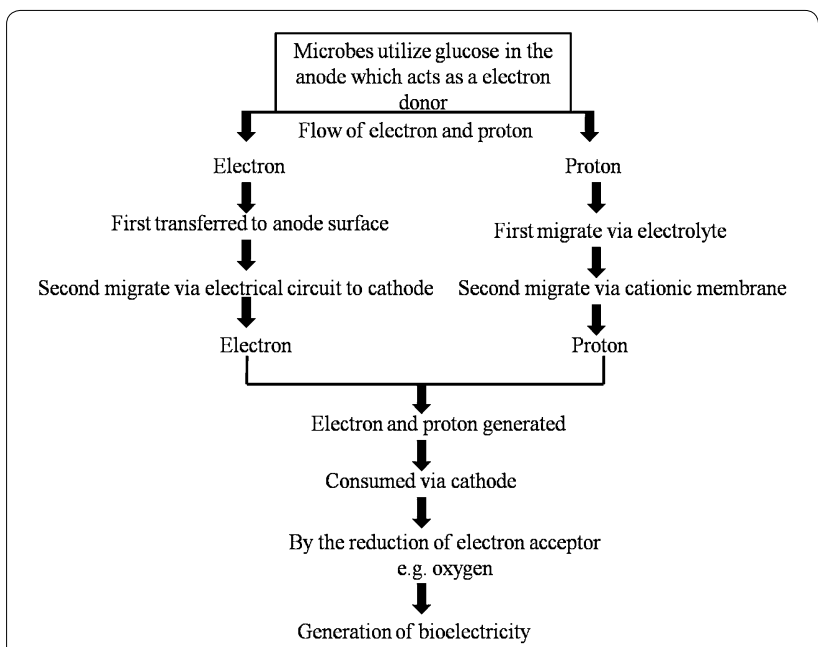

Fig. 2 Schematic representation of the production of bioelectricity from microbes

and pectin (Niessen et al. 2005, 2006; Rezaei et al. 2007) were also employed. In addition, complex carbon sources present in wastewaters from different sources were also tested for bioenergy production (Liu et al. 2004; Rabaey et al. 2005a, b). Many studies have been performed, which have utilized wastewaters from different sources such as starch processing (Gil et al. 2003) and wastewaters coming from the meat packing industry (Heilmann and Logan 2006), swine farms (Min et al. 2005) and food processing (Oh and Logan 2005) and potato-producing units (Rabaey et al. 2005a, b). Solid agricultural wastes such as corn stover (Zuo et al. 2006) and carbohydrates (Scott and Murano 2007) have also been tested as fuel after being pretreated. Studies have demonstrated that these organic sources affect the power output of MFCs and the power density usually varies from 1 to $3600 \mathrm{~mW} / \mathrm{m}^{2}$, with most values lying between 10 and $1000 \mathrm{~mW} / \mathrm{m}^{2}$. Table 1 depicts various substrates that are utilized for electricity production in an MFC, and their power output. Similarly a wide variety of microorganisms have been used for electricity generation in MFC. Potter (1911), for the first time employed Saccharomyces cerevisae and bacteria such as Escherichia coli for power generation in MFC. Studies have demonstrated that pure microbial cultures have limitations for technical application because of necessity for sterile conditions, which leads to high cost, whereas mixed cultures or microbial consortia have been shown to be robust and more productive than pure strains. In addition, extraction can be easily achieved from natural sources (Ha et al. 2008). Table 2 shows the list of microorganisms commonly employed for electricity generation in the MFC.

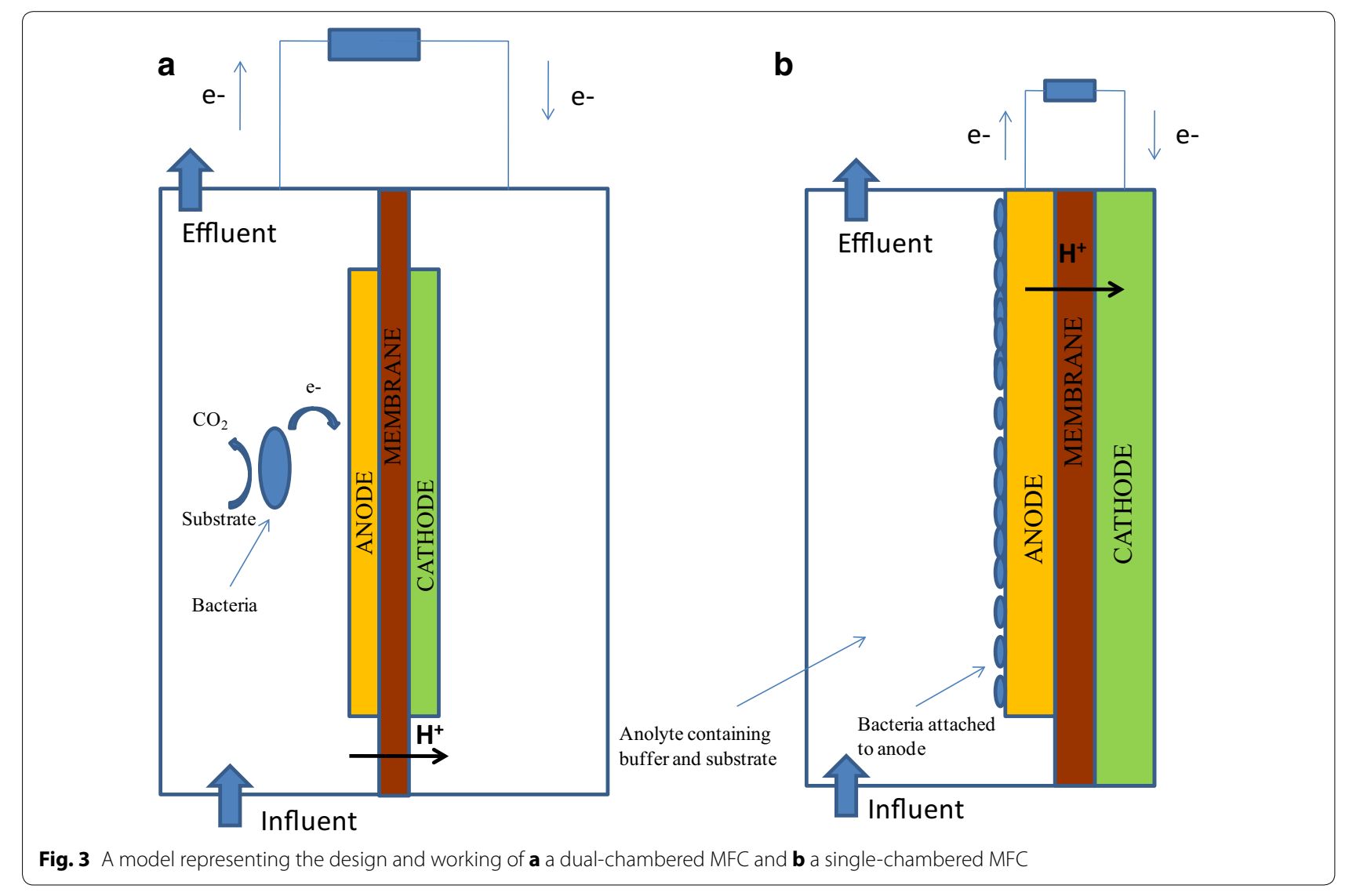


Table 1 A list of substrates used in MFCs

\begin{tabular}{|c|c|c|c|c|c|}
\hline S. no. & Substrates & Concentration & Microorganism & $\begin{array}{l}\text { Current den- } \\
\text { sity }\left(\mathrm{mA} / \mathrm{cm}^{2}\right)\end{array}$ & Reference \\
\hline 1 & Cellulose & $4 \mathrm{~g} / \mathrm{L}$ & Pure culture of Enterobacter cloacae & 0.02 & Rezaei et al. (2009) \\
\hline 2 & 1,2-Dichloroethane & $99 \mathrm{mg} / \mathrm{L}$ & $\begin{array}{l}\text { Microbial consortia from acetate } \\
\text { enriched MFC }\end{array}$ & 0.008 & Pham et al. (2009) \\
\hline 3 & Furfural & $6.8 \mathrm{mM}$ & $\begin{array}{l}\text { Pre-acclimated bacteria from anode of } \\
\text { a ferricyanide-cathode MFC }\end{array}$ & 0.17 & Luo et al. (2010) \\
\hline 4 & Lactate & $18 \mathrm{mM}$ & Pure culture of S. oneidensis MR-1 & 0.005 & Manohar and Mansfeld (2009) \\
\hline 5 & Landfill leachate & $6000 \mathrm{mg} / \mathrm{L}$ & Leachate and sludge & 0.0004 & Greenman et al. (2009) \\
\hline 6 & Phenol & $400 \mathrm{mg} / \mathrm{L}$ & $\begin{array}{l}\text { Mixed aerobic activated sludge and } \\
\text { anaerobic sludge }(1: 1, v / v)\end{array}$ & 0.1 & Luo et al. (2009) \\
\hline 7 & Sucrose & $2674 \mathrm{mg} / \mathrm{L}$ & Anaerobic sludge from septic tank & 0.19 & $\begin{array}{l}\text { Behera and Ghangrekar } \\
\text { (2009) }\end{array}$ \\
\hline 8. & Beer brewery wastewater & $600 \mathrm{mg} / \mathrm{L}$ & Anaerobic mixed consortia & 0.18 & Wen et al. (2009) \\
\hline 9 & $\begin{array}{l}\text { Chocolate industry waste- } \\
\text { water }\end{array}$ & 1459 mg/L COD & Activated sludge & 0.302 & Patil et al. (2009) \\
\hline 10 & Domestic wastewater & 600 mg/L & Anaerobic sludge & 0.06 & Wang et al. (2009) \\
\hline 11 & Protein-rich wastewater & $1.75 \mathrm{~g} / \mathrm{L} C O D$ & Mesophilic anaerobic sludge & 0.008 & Liu et al. $(2009 a, b)$ \\
\hline 12 & $\begin{array}{l}\text { Starch processing waste- } \\
\text { water }\end{array}$ & $4852 \mathrm{mg} / \mathrm{L} C O D$ & Starch processing wastewater & 0.09 & Lu et al. (2009) \\
\hline 13 & Synthetic wastewater & 16 g COD/day & $\begin{array}{l}\text { Granular sludge from an upflow } \\
\text { anaerobic sludge blanket reactor }\end{array}$ & 0.017 & Aldrovandi et al. (2009) \\
\hline 14 & Synthetic wastewater & $510 \mathrm{mg} / \mathrm{L}$ & $\begin{array}{l}\text { Anaerobic culture from a preexisting } \\
\text { MFC }\end{array}$ & 0.008 & $\begin{array}{l}\text { Jadhav and Ghangrekar } \\
\text { (2009) }\end{array}$ \\
\hline 15 & Food-industry wastes & 8169 CO mg/L & Aerobic sludge & 0.025 & Quezada et al. (2010) \\
\hline 16 & Vegetable based waste & $0.98 \mathrm{~kg} \mathrm{COD} / \mathrm{m} 3$-day & Anaerobic acidogenic mixed consortia & 0.0329 & Mohanakrishna et al. (2010) \\
\hline 17 & Swine wastewater & $60 \mathrm{CO} \mathrm{gm} / \mathrm{L}$ & paddy field soil & 0.700 & Ichihashi and Hirooka (2012) \\
\hline 18 & Slaughterhouse wastewater & 900 COD mg/L & Granular anaerobic sludge inoculum & 0.130 & Katuri et al. (2012) \\
\hline 19 & Food waste & $16 \mathrm{~g} / \mathrm{L}$ & Anaerobic culture & 0.045 & Choi et al. (2011) \\
\hline 20 & Rice straw hydrolysate & $400 \mathrm{mg} / \mathrm{mL}$ & Desulfobulbus and Clostridium & 137.6 & Wang (2014) \\
\hline
\end{tabular}

Use of waste/xenobiotics for electricity generation The functioning and efficiency of MFC largely depends upon the type of materials employed for metabolism by microbes (Logan and Regan 2006a, b). Many workers have reported utilization of simple and complex organic/ inorganic sources present in wastewaters from different origin as a substrate for electricity production. The use of wastewater as a source of substrate has a dual advantage; first, the electricity produced is cheap, and second, it leads treatment of wastewater. Extensive research has shown that these complex substrates such as agro wastes are oxidized by different group of microorganisms and cause generation of electricity. In this section, we have discussed some uncommon wastes and pollutants, which are utilized in MFC for electricity generation.

\section{Hexavalent chromium}

Microbial fuel cells (MFCs) are considered as an efficient technology which effectively utilizes wastewater for energy generation (Logan and Regan 2006a, b).
Chromium is widely used in number of industrial applications such as leather tanning, metallurgy, electroplating, and as a wood preservatives. Chromium exists in the aqueous solution either as hexavalent chromium $[\mathrm{Cr}(\mathrm{VI})]$ or trivalent chromium [Cr(III)], in which $\mathrm{Cr}(\mathrm{VI})$ is more hazardous due to its mutagenic and carcinogenic properties (Humphries et al. 2004). Therefore, there is a need for detoxification of hexavalent chromium [Cr(VI)]. Studies have shown that chemical or electrochemical reduction of hexavalent chromium [ $\mathrm{Cr}(\mathrm{VI})]$ into non-toxic trivalent chromium [ $\mathrm{Cr}(\mathrm{III})]$ is the most preferred method for removing its toxicity. Other approaches such as ion exchange resins, filtration and direct chemical reduction are also employed (Kurniawan et al. 2006). A major drawback of utilizing these technologies is that these technologies require high-energy inputs and cause production of by-products, which itself are pollutants. Many reports have shown that acidic hexavalent chromium $[\mathrm{Cr}(\mathrm{VI})]$ can also be possibly applied as the cathodic electron acceptor in the MFC through the reaction: 
Table 2 Microorganism employed for bioelectricity generation in MFC

\begin{tabular}{|c|c|c|c|c|c|}
\hline S.no. & Microorganism & Substrate/co-substrate & Power density $\left(\mathrm{mW} / \mathrm{m}^{2}\right)$ & Mediator & References \\
\hline 1 & $\begin{array}{l}\text { Shewanella oneidensis } \\
\text { strain } 14063\end{array}$ & Sodium pyruvate & $\begin{array}{l}>40 \text { at acid orange } 7(\mathrm{AO} 7) \\
\text { initial conc. is } 70 \mathrm{mg} / \mathrm{l}\end{array}$ & $\begin{array}{l}\text { 1-amino-2 Naphthol, one } \\
\text { of the metabolites of AO7 } \\
\text { reductive decolourisation. }\end{array}$ & Fernando et al. (2012) \\
\hline 2 & Shewanella oneidensis & Lactate & 24 & $\begin{array}{l}\text { Anthraquinone-2,6-disul- } \\
\text { fonate (AQDS) }\end{array}$ & Ringeisen et al. (2006)) \\
\hline 3 & Klebsiella pneumoniae & Glucose & NA & $\begin{array}{l}\text { HNQ as mediator biomin- } \\
\text { eralized manganese as } \\
\text { electron acceptor }\end{array}$ & Menicucci et al. (2006) \\
\hline 4 & Rhodoferax ferrireducens & $\begin{array}{l}\text { Glucose, xylose sucrose, } \\
\text { maltose }\end{array}$ & 158 & Mediator-less MFC & Liu et al. (2006) \\
\hline 5 & $\begin{array}{l}\text { Klebsiella pneumoniae } \\
\text { strain L17 }\end{array}$ & Glucose & 34.77 & Mediator-less MFC & Liu et al. $(2009 a, b)$ \\
\hline 6 & $\begin{array}{l}\text { Nocardiopsis sp. KNU (S } \\
\text { strain) }\end{array}$ & CMC & 162 & Mediator-less MFC & Sedky et al. (2012) \\
\hline 7 & $\begin{array}{l}\text { Streptomyces enissocaesilis } \\
\text { KNU (K strains) }\end{array}$ & CMC & 145 & Mediator-less MFC & Sedky et al. (2012) \\
\hline 8 & Pseudomonas species & Luria-Bertani (LB) medium & NA & phenazine-1- carboxamide & Pham et al. (2008) \\
\hline 9 & Pseudomonas sp. & Peptone & 979 & Methylene blue & Daniel et al. (2009) \\
\hline 10 & Rhodoferax ferrireducens & Glucose & NA & Mediator-less MFC & Vet and Rutgers (2007) \\
\hline 11 & Escherichia coli strain K-12 & Sucrose & 215 & Mediator-less MFC & $\begin{array}{l}\text { Zheng and Nirmalakhan- } \\
\text { dan (2010) }\end{array}$ \\
\hline
\end{tabular}

$$
\mathrm{Cr}_{2} \mathrm{O}_{7}^{2-}+14 \mathrm{H}^{+}+6 \mathrm{e}^{-} \rightarrow 2 \mathrm{Cr}^{3+}+7 \mathrm{H}_{2} \mathrm{O}
$$

Under standard conditions (i.e., $\mathrm{pH}=7$ ), the above half-cell reaction has a redox potential $\left(\mathrm{E}_{0}\right)$ of $1.33 \mathrm{~V}$ showing that the overall reaction in the MFC for power generation is thermodynamically favorable. Therefore, reduction of hexavalent chromium can be coupled with electicity generation using MFC and can be applied in $\mathrm{Cr}(\mathrm{VI})$ wastewater treatment (Tandukar et al. 2009). In this study, reduction of $\mathrm{Cr}(\mathrm{VI})$ in the cathode of an MFC was performed. Also putative $\mathrm{Cr}(\mathrm{VI})$ reducing microorganisms were identified, which belong to Trichococcus pasteurii and Pseudomonas aeruginosa. The MFC was continuously monitored for $\mathrm{Cr}(\mathrm{VI})$ reduction and power generation. Acetate was provided to the anode compartment as substrate and bicarbonate was added to the cathode compartment as the sole external carbon source. The contribution of biomass decay and abiotic processes on $\mathrm{Cr}(\mathrm{VI})$ reduction was minimal, confirming that most of the $\mathrm{Cr}(\mathrm{VI})$ reduction was assisted by microbial activity in the cathode, which utilizes electrons and protons generated from the oxidation of acetate in the anode compartment. Relatively fast $\mathrm{Cr}(\mathrm{VI})$ reduction was observed at initial $\mathrm{Cr}(\mathrm{VI})$ concentrations below $80 \mathrm{mg} / \mathrm{L}$. However, at $80 \mathrm{mg} \mathrm{Cr}(\mathrm{VI}) / \mathrm{L}, \mathrm{Cr}(\mathrm{VI})$ reduction was extremely slow. A maximum $\mathrm{Cr}(\mathrm{VI})$ reduction rate of $0.46 \mathrm{mg} \mathrm{Cr}(\mathrm{VI}) / \mathrm{g}$ VSS.h was achieved, which resulted in a current and power density of $123.4 \mathrm{~mA} / \mathrm{m}^{2}$ and $55.5 \mathrm{~mW} / \mathrm{m}^{2}$, respectively. The reduced chromium was not detectable in the supernatant of the catholyte which indicated complete removal of chromium as $\mathrm{Cr}(\mathrm{OH})$ precipitate. This study demonstrated that although the reduction of $\mathrm{Cr}(\mathrm{VI})$ took place efficiently, the power output was low in comparison with the conventional anaerobic or aerobic process (Tandukar et al. 2009; Molokwane et al. 2008), which was a drawback for using MFCs for actual bioremediation on $\mathrm{Cr}(\mathrm{VI})$-contaminated sites. Reports have shown that by increasing cathode surface area and using small anode relative to cathode area can improve power production from MFCs (Rismani-Yazidi et al. 2008). It was anticipated that a large biocathodic surface area may allow the packing of more electrochemically active microorganisms and provide the bacteria and $\mathrm{Cr}(\mathrm{VI})$ with more reaction sites. Consequently, it will greatly enhance reactor performance by high $\mathrm{Cr}(\mathrm{VI})$ reduction rate and power production. In many studies, graphite fiber and granule graphite have been used successfully to enlarge the surface area of biocathode for $\mathrm{O}_{2}$ reduction and has improved power production greatly (You et al. 2009). Therefore, the use of graphite granule may increase power production and $\mathrm{Cr}(\mathrm{VI})$ reduction rate. To test this hypothesis, a two-chamber MFC reactor (Wang et al. 2008) was employed for $\mathrm{Cr}(\mathrm{VI})$ reduction containing $\mathrm{Cr}(\mathrm{VI})$-contaminated soil sole inoculum. The power generated by the MFC and the biomass was monitored for initial $\mathrm{Cr}(\mathrm{VI})$ concentrations ranging from 12.8 to $39.2 \mathrm{mg} / \mathrm{L}$. The obtained biomass ranged from 1.9 to $2.2 \mathrm{~g} / / \mathrm{L}$ corresponding to $\mathrm{Cr}(\mathrm{VI})$ concentration from 12.8 
to $39.2 \mathrm{mg} / \mathrm{L}$. The maximum power production increased from 0.3 to $2.4 \mathrm{~W} / \mathrm{m}^{3}$ with initial $\mathrm{Cr}(\mathrm{VI})$ concentrations of $12.8-39.2 \mathrm{mg} / \mathrm{L}$, demonstrating that power production was directly relative to the initial $\mathrm{Cr}(\mathrm{VI})$ concentration. In another study, alkaline hexavalent chromium containing wastewater was successfully treated in MFC. It was observed that $10 \mathrm{mg} / \mathrm{L}$ chromium was completely reduced in $45 \mathrm{~h}$ with power production of $21.4 \mathrm{~mW} / \mathrm{m}^{2}$ (Gangadharan and Nambi 2015). Xafenias et al. (2015) also studied chromium reduction in the presence of anaerobic sludge, $\mathrm{Cr}(\mathrm{VI})$ at $100 \mathrm{mg} / \mathrm{L}$ was completely removed within $48 \mathrm{~h}$ of incubation. The maximum power density of $767.01 \mathrm{~mW} / \mathrm{m}^{2}\left(2.08 \mathrm{~mA} / \mathrm{m}^{2}\right)$ was achieved during this period.

\section{Agro wastes}

The waste material arising from various agricultural operations such as farming, poultry processing industries, slaughter houses, and agro industries is collectively termed as agro wastes. It is rich in COD. Some of the agro wastes used for bioelectricity generation are as follows: starch obtained from cassava is an important economic product produced by many traditional and rural agro industries situated in Southeast Asia, Africa and Central America. During production of starch from cassava, high amount of starch-rich wastewater is released, having a very high chemical oxygen demand (COD), biochemical oxygen demand (BOD), and total solids (Peters and Ngai 2000; Kaewkannetra et al. 2009). It is also rich in cyanoglycosides. These cyanoglycosides hydrolyze to form cyanide, which is a common component of cassava wastewater. Cyanide concentrations have been reported as high as $200 \mathrm{mg} / \mathrm{L}$ from many wastewaters. Therefore, it is necessary that cassava wastewater is properly treated prior to its release into the environment (Kaewkannetra et al. 2009). Many workers have reported different techniques for treatment of cassava wastewater. However, most of the techniques are expensive. Therefore, treatment of cassava wastewater and production of electricity using MFC has been found to be suitable for this purpose (Rabaey and Verstrate 2005; Lu et al. 2009). Kaewkannetra et al. (2009) have utilized cassava wastewater for generation of electricity by employing MFC. For this process, an MFC was constructed, which utilized sludge arising from wastewater treatment plant from a cassava mill factory. The wastewater had a high organic content of $16,000 \mathrm{mg} / \mathrm{L}$ and is comparable to the organic matter present in similar large-scale starch processing industries (Kaewkannetra et al. 2009). The results of this study showed that COD removal was approximately $88 \%$ within $120 \mathrm{~h}$ and maximum power generated was $1771 \mathrm{~mW} / \mathrm{m}^{2}$. In another study, it was shown that by increasing the $\mathrm{pH}$ of anode chamber, the production of electricity can be increased. A single-chambered MFC was used with cassava mill wastewater having COD $1086 \mathrm{mg} / \mathrm{L}$. The $\mathrm{pH}$ was increased from 5.0 to 9.0. It was observed that the maximum power density generated was $22.19 \mathrm{~W} / \mathrm{m}^{3}$ at $\mathrm{pH}-9$ (Prasertsung et al. 2012). These results clearly indicated that cassava mill wastewater has a great potential to benefit from the use of MFCs to simultaneously treat and generate electricity as it is a readily biodegradable waste source.

Many studies have shown that cellulose can also be employed for generation of electricity using MFC (Niessen et al. 2005). Rismani-Yazidi et al. (2007) have employed cellulose for bioelectricity generation using microorganisms from rumen of cattle. Ren et al. (2008) employed a dual-chambered MFC for electricity generation using a binary culture of cellulose-degrading bacteria Clostridium cellulolyticum and electrochemically active bacteria Geobacter sulfurreducens. In fed-batch mode, maximum power density obtained was $143 \mathrm{~mW} /$ $\mathrm{m}^{2}$ with $1 \mathrm{~g} / \mathrm{L}$ carboxymethyl cellulose (CMC). In a study by Rezaei et al. (2009), cellulose-degrading bacteria was first enriched in a special U-tube MFC from wastewater. The dominant bacteria in this enriched culture was Enterobacter cloacae strain FR. When cellulose at a concentration of $4 \mathrm{~g} / \mathrm{L}$ was fed in this MFC, maximum power density of $4.9 \mathrm{~mW} / \mathrm{m}^{2}$ was obtained. Sedky et al. (2012) have utilized cellulose as substrate for electricity generation using a dual-chambered MFC. In their study, cellulose-degrading bacteria Nocardiopsis sp. KNU and Streptomyces enissocaesilis KNU were employed for cellulose degradation in anode and the cathode contained $50 \mathrm{mM}$ ferricyanide. With $1 \mathrm{~g} / \mathrm{L}$ cellulose, the maximum power density for the mixed culture was $188 \mathrm{~mW} /$ $\mathrm{m}^{2}$. Use of vegetable waste for bioelectricity production was also investigated by Clauwaert et al. (2008). In their study, a single-chambered MFC containing $0.5 \mathrm{~g} \mathrm{COD} / \mathrm{L}$ clover sap was employed for electricity generation. Maximum power density obtained in this study ranged from 28 to $70 \mathrm{~mW} / \mathrm{m}^{3}$. Recent studies have shown that cellulose from different sources such as wheat straw, rice mill wastewater, corn stover, and Canna indica could be partially degraded by electrophilc bacteria for electricity generation (Zang et al. 2010). In these studies, the biomass was pretreated to convert it into cellulose and hemicelluloses and these hydrolysates were employed for electricity generation. The tubers of Dioscorea zingiberensis are used to separate diosgenin, which is an important precursor for the synthesis of steroid hormone drugs. These industries produce large amounts of wastewater rich in sugars, fatty esters and $\mathrm{N}$-containing compounds. In a study by $\mathrm{Li}$ and $\mathrm{Ni}$ (2011), a two-chamber MFC was used to treat this wastewater and to generate electricity. At a concentration of $3000 \mathrm{mg}-\mathrm{COD} / \mathrm{L}$, the maximum 
power density achieved was $175 \mathrm{~mW} / \mathrm{m}^{2}$. Brewery wastewater was used for electricity production in doublechamber MFC. Carbon fiber was used as anode and plain carbon felt with biofilm as cathode. It was observed that with hydraulic retention time (HRT) of $14.7 \mathrm{~h}$, a relatively high chemical oxygen demand (COD) removal efficiency of 91.7-95.7\% was achieved under long-term stable operation. The MFC exhibited a voltage of $0.434 \mathrm{~V}$ and a maximum power density of $830 \mathrm{~mW} / \mathrm{m}^{3}$ at an external resistance of $300 \Omega$ (Wen et al. 2010). Many reports are available which use slaughter house wastewater for generation of electricity. Slaughter house wastewater contains high amount of proteins, fats and carbohydrates, which is an ideal source for generation of electricity. A dual-chambered microbial fuel cell, fed with slaughterhouse wastewater with an anaerobic mixed sludge as a source of inoculum was used. It was observed that when wastewater at a concentration of $900 \mathrm{mg}-\mathrm{COD} / \mathrm{L}$ was fed, a maximum power density of $578 \mathrm{~mW} / \mathrm{m}^{2}$ was obtained (Katuri et al. 2012).

In a different study, Chaturvedi et al. (2013), studied degradation of chicken feathers by a strain of $P$. aeruginosa with concomitant electricity production in MFC. It was observed that maximum voltage corresponding to $141 \mathrm{mV}$ was observed after 14 days of incubation. Maximum power density of $1206.78 \mathrm{~mW} / \mathrm{m}^{2}$ and maximum current density of $8.6 \mathrm{~mA} / \mathrm{m}^{2}$ were observed. The results showed that chicken feathers can be successfully employed as a cheap substrate for electricity production in MFC. In a different study, rice straw hydrolysate was used for electricity production by Wang et al. (2014). In presence of $400 \mathrm{mg}-\mathrm{COD} / \mathrm{L}$, a power density of $137.6 \pm 15.5 \mathrm{~mW} / \mathrm{m}^{2}$ was obtained. Further, it was noted that Clostridium and Desulfobulbus were the main bacteria involved in electricity generation.

\section{Azo dyes}

Many reports have confirmed that bioelectricity can also be generated using waste arising from different sources (Feng et al. 2008; He et al. 2005) and thus complex organic compounds present in waste can be removed with concomitant energy production. However, waste arising from different sources consists of a mixture of compounds, in which some are oxidisable and some are not. These contaminants cannot be degraded by oxidation at anode due to their high redox potentials. However, efficient treatment of wastewater means complete removal of contaminants. Therefore, to remove these contaminants, some modifications in MFC technology were performed. The idea emerged from reports which showed that microorganisms present in biocathode can remove nitrogen (Virdis et al. 2008; Jia et al. 2008). However, this process was not applicable because of its demerit such as longer start up time and lower power generation (Clauwaert et al. 2007). This drawback was overcome by the use of abiotic cathode such as potassium ferricyanide-feeding cathode (Schröder et al. 2003), which was far more efficient that biocathode. But later on, it was observed that the running cost of this cathode was high and recycling of ferricyanide was difficult. It was noticed that various pollutants are present in wastewaters which have high redox potentials, such as nitro aromatic compounds, chlorinated aromatic compounds, and some metal ions (e.g., chromium (VI) (Wang et al. 2008). Therefore, these pollutants can be used as an alternative to potassium ferricyanide. In this context, it was assumed that azo dyes, which are widely used in textile industries and are one of the major pollutants in wastewaters, can be used as electron acceptors at cathode (Xu et al. 2007). All the azo dyes are characterized by the presence of the $-\mathrm{N}=\mathrm{N}-$ bond, which can be employed as an electron acceptor. The reduction reactions that may be involved in the cathode chamber are described as follows (Menek and Karaman 2005), in which the $-\mathrm{N}=\mathrm{N}$ - double bond was reduced to hydrazo (A) or amine (B), via the consumption of two or four electrons.

$$
\begin{aligned}
& -\mathrm{N}=\mathrm{N}-+2 \mathrm{e}+2 \mathrm{H}^{+} \rightarrow-\mathrm{NH}-\mathrm{NH}- \\
& -\mathrm{N}=\mathrm{N}-+4 \mathrm{e}+4 \mathrm{H}^{+} \rightarrow-\mathrm{NH}_{2}-\mathrm{NH}_{2}-
\end{aligned}
$$

Liu et al. (2009a, b) have reported production of electricity by employing microbial fuel cells using azo dyes as the cathode oxidants and using Klebsiella pneumoniae strain L17 in the anode. For this study, a dual-chamber MFC was constructed, and the biocatalyst employed was Klebsiella pneumoniae strain L17 fed with glucose. In this study, three azo dyes namely orange I, orange II, and methyl orange were employed. The results demonstrated that the azo dyes were successfully degraded at the cathode. In addition, power output was highly dependent on the catholyte $\mathrm{pH}$ and the dye molecular structure. When $\mathrm{pH}$ was varied from 3.0 to 9.0, the maximum power density decreased from 34.77 to $1.51 \mathrm{~mW} / \mathrm{m}^{2}$. The performances of the MFC fed with different azo dyes can be ranked from good to poor as $\mathrm{MO}>$ orange I $>$ orange II.

In a different study, Sun et al. (2009) investigated the removal of Congo red in a single-chambered MFC. In an air cathode single-chambered MFC, equal volumes of aerobic and anaerobic sludge were used as inoculum. The growth medium contained glucose $500 \mathrm{mg}-\mathrm{COD} / \mathrm{L}$ and Congo red $300 \mathrm{mg} / \mathrm{L}$. The MFC was continuously operated for more than 4 months at a fixed external resistor of $500 \Omega$. It was observed that MFC voltage gradually decreased over time. The cathode potential decreased rapidly, while that of the anode remained the same. This suggests that the voltage decrease in the MFC supplied 
with Congo red was primarily due to the deterioration in cathode performance rather than the suppression of the metabolic activity of anodophilic bacteria. The stable anode potential also indicated that the microbial community was well acclimated. The peak potentials of the cathode decreased from 0.10 to $-0.11 \mathrm{~V}$. The results on degradation of Congo red showed that the anaerobic cleavage of the azo bonds of Congo red converted them to form aromatic amines. The electrons arising from glucose (electron donor) by bacteria at the anode were partly transported to the azo dye for reductive cleavage of the azo bond (Sun et al. 2011a, b; Chen et al. 2010). Thus, biological reduction of Congo red which occurred in the presence of glucose is mainly responsible for the degradation of Congo red. This degradation mechanism is similar to the mechanism, which occurs in a conventional anaerobic reactor (Dos Santos et al. 2007; Pandey et al. 2007). In addition, in this study, the microbes taking part in the reduction of Congo red were also identified by PCR-DGGE approach. The bacteria were identified as the members of the genera Azospirillum, Methylobacterium, Rhodobacter, Desulfovibrio, Trichococcus, and Bacteroides were more abundant in the presence of Congo red. Most of the bacteria were found to be aerobic or facultative bacteria, which are often highly versatile in their abilities to degrade aromatic and heterocyclic compounds (Chen et al. 1993; Barkovskii et al. 1995; Roldán et al. 1998; Song et al. 2003; Fournier et al. 2005).

Bakhshian et al. (2011) studied the enzymatic decolorization of reactive blue 221 (RB221) using laccase in a dual-chamber MFC. A dual-chamber MFC was used in which molasses was utilized as substrate in a fedbatch mode in the anode chamber, and dye decolorization catalyzed with an enzymatic reaction by laccase was evaluated simultaneously in the cathode. Results demonstrated that at dye concentration of $112.5 \mathrm{mg} / \mathrm{L}$, maximum power density of $27.5 \mathrm{~mW} / \mathrm{m}^{2}$ was achieved. In a different study, simultaneous bioelectricity generation and dye degradation was performed with the help of a combined anaerobic-aerobic process. The anaerobic system was a typical single-chambered microbial fuel cell which utilized acid navy blue $r$ (ANB) dye along with glucose as growth substrate to generate electricity. The dye decolorization followed pseudo first-order kinetics. It was observed that coulombic efficiency and power density were at peak values at $10.36 \%$ and $2236 \mathrm{~mW} / \mathrm{m}^{2}$, respectively, for $200 \mathrm{ppm}$ of ANB (Khan et al. 2015a, b). In a recent study, a new device called microbial fuel cellcoupled constructed wetland (CW-MFC) was construced to treat the wastewater and produce energy. In this study, degradation of recalcitrant dye reactive brilliant red X-3B (ABRX3) was decolorized. It was observed that decolorization rate and the electricity production increased to a peak value of $95.6 \%$ and $0.852 \mathrm{~W} / \mathrm{m}^{3}$, respectively, when the COD concentration was $300 \mathrm{mg} / \mathrm{L}$ while the ABRX3 proportion was $30 \%$ (Fang et al 2015).

\section{Selenite}

Selenium and its various derivatives such as selenite $\left(\mathrm{SeO}_{3}{ }^{2-}\right)$ and selenate $\left(\mathrm{SeO}_{4}^{2}\right)$ are widely used in industries such as glass manufacturing and electronic industries. Thus, wastewater arising from these industries contains high amounts of selenium and its derivatives. Many studies have shown that selenite is more toxic than selenate to aquatic invertebrates and fishes (Hamilton 2004) and it is readily accumulated by aquatic plants and thus causes bioaccumulation in higher organisms (Riedel et al. 1991). Selenium also comes into environment through sewage sludge, fly ash from coal-fired power plants, oil refineries, and mining of metal ores (Hamilton 2004; Lemly 1997). Studies have confirmed that moderately high concentrations of Se cause both acute and chronic toxicity in aquatic organisms (Catal et al. 2008; Kashiwa et al. 2000; Rovira et al. 2008). Therefore, several methods have been developed for removal of selenium from environment (Banuelos and Lin 2005). Few reports have shown that selenium compounds can be converted to elemental selenium by various microbes, which is less toxic (Fujita et al. 2002; Kashiwa et al. 2000). Catal et al. (2009) have investigated the application of MFC technology in reduction of selenium and production of electricity using seleniumcontaining waste. In their study, a single-chamber air cathode MFC was constructed. Sodium acetate $(2 \mathrm{~g} / \mathrm{L})$ or glucose $(1.2 \mathrm{~g} / \mathrm{L})$ was employed as carbon source. Artificial wastewater was created by dissolving sodium selenite in minimal medium solution containing either acetate or glucose. The MFCs were inoculated with a mixed bacterial culture. Results showed that a voltage of $0.54 \mathrm{~V}$ was produced using Se-free medium solution, corresponding to an anodic power density of $2900 \mathrm{~mW} / \mathrm{m}^{2}$. In addition, it was observed that the power output was not affected when the medium solution was replaced with solutions containing 1-25 mg/L. However, further increase of selenite to $50 \mathrm{mg} / \mathrm{L}$ resulted in a $13-17 \%$ decrease in voltage output. When selenite was increased to $75 \mathrm{mg} / \mathrm{L}$, the voltage and power density decreased to $0.41 \mathrm{~V}$ and $2200 \mathrm{~mW} / \mathrm{m}^{2}$, respectively.

\section{Nitrate}

The presence of nitrate in water is increasing tremendously due to excessive use of nitrate-based fertilizers and through animal waste (Chebotareva and Nyokong 1997). Nitrate being a non-toxic compound can be easily transformed to Nitrite $\left(\mathrm{NO}_{2}^{-}\right)$in human body, which causes a disease namely "blue baby syndrome", which is normally observed in infants. Nitrate can be converted 
into N-nitroso compounds which are carcinogenic in humans (Claudio 2005). Therefore, many methods have been designed to treat nitrate-contaminated water. Some of the commonly employed methods are electrochemical treatment, ion exchange (IE), reverse osmosis (RO), electrodialysis (ED), and heterogeneous catalysis (HC) (Park and Yoo 2009). A major drawback of these methods is that most of them are expensive (Till et al. 1998). Recently, use of MFC technology for removal of nitrate has gained importance due to ease and feasibility of this process. Several studies have been carried out for reduction of nitrate to nitrite or nitrogen gas at cathode, few workers have employed a metal catalyst (Polatides and Kyriacou 2005) or microorganisms as catalysts on cathode electrode (He and Angenent 2006). In these studies, the anode was employed as a power source (Fang et al. 2011) or in some studies external power supply was used, (Dima et al. 2005) or cathode, which served as electron donor (Lovley 2011). In few studies, electrochemical denitrification process to remove nitrate ions was employed at cathode chamber of bioelectrochemical denitrification system (Kondaveeti and Min 2012). Three different cathodes of Pt-coated electrode, biocathode, and plain carbon were used to investigate their performance in nitrate removal. An H-type two-chambered bioelectrochemical denitrification system was employed. The results showed that biocathode showed a higher removal percentage $(82.4 \%)$ followed by a platinum $(80.4 \%)$ and carbon cathode $(67.8 \%)$. The biocathode and platinum achieved a higher removal rate of $0.183 \mathrm{mg} \mathrm{NO} / \mathrm{cm}^{2}$ in comparison with plain carbon $\left(0.151 \mathrm{mg} \mathrm{NO} / \mathrm{cm}^{2}\right)$. In other studies, denitrification with biocathode in cathode chamber using an bioanode as the electron donor source was carried out and could achieve a maximum of $22 \%$ nitrate removal in 7 days $(168 \mathrm{~h})$ operation with a removal rate of $\left(0.0436 \mathrm{mg} \mathrm{NO} / \mathrm{cm}^{2}\right)$ (Dima et al. 2005; Park et al. 2005). In addition, it was observed that nitrate removal percentage was increased by increasing the cell voltage from 0.5 to $0.7 \mathrm{~V}$ for all types of cathodes. In another study by Fang et al. (2011), nitrate ions were used as the oxidant in MFC to generate electricity from organic compounds with simultaneous nitrate removal. The MFC using nitrate as oxidant could generate a voltage of $111 \mathrm{mV}(1000 \Omega)$ with a plain carbon cathode. The maximum power density achieved was $7.2 \mathrm{~mW} / \mathrm{m}^{2}$ with a $470 \Omega$ resistor. In the presence of Pt catalyst dispersed on cathode, the cell voltage was significantly increased up to $450 \mathrm{mV}$ and the power density was $117.7 \mathrm{~mW} / \mathrm{m}^{2}$, which was 16 times higher than the value without Pt catalyst. In a different study, electricity generated from the MFC is applied to the bioelectrical reactor (BER) directly as electrical stimulation for enhancement of bacterial denitrification to remove nitrate effectively from groundwater.
The results showed that with nitrate removal a maximum power density of $502.5 \mathrm{~mW} / \mathrm{m}^{2}$ and voltage outputs ranging from 500 to $700 \mathrm{mV}$ were observed (Zhang et al. 2014). In some studies, nitrate and sulfite have been removed simultaneously. In a study by Cai and Zheng (2013), a two-chamber MFCs was constructed to remove sulfide and nitrate using activated sludge. When the external resistance was $1000 \Omega$, the initial concentrations of sulfide and nitrate were about 60 and $10.5 \mathrm{mg} / \mathrm{L}$, respectively; maximum current density of the MFC was $138.31 \mathrm{~mA} / \mathrm{m}^{2}$. The main end products were nitrogen and sulfate (Cai and Zheng 2013). In another study, Cucu et al. (2016) have studied denitrification in MFC. The anode consisted of cow manure and fruit waste and the cathode consisted of cow manure and soil. With initial $\mathrm{COD} /$ nitrate nitrogen ratio from 2 to 40 at the cathode while keeping the anode ratio fixed at 100 . Maximum current density of $190 \pm 9.1 \mathrm{~mA} / \mathrm{m}^{2}$ and power density of $31.92 \pm 4 \mathrm{~mW} / \mathrm{m}^{2}$ of electrode surface area. A comparative analysis of current and power output of all the xenobiotics and wastes is depicted in Table 3.

\section{Commercialization of MFC}

Success of any technology depends upon its commercialization when it is marketed in huge amounts and used by a large number of people. Since MFC deals with production of electricity by employing waste materials, its commercialization will offer several advantages such as:

1. Production of low-cost electricity from waste materials.

2. The electricity will be produced all round the year since waste and xenobiotics are readily available.

3. People would be able to produce electricity in their homes.

4. This technology will be helpful for the people living in poor countries such as Africa where huge infrastructure required for set of energy production plants is not available.

5. MFC will lead to clean up of wastes and xenobiotics. So, it can be used as an alternate method for bioremediation.

The output of MFC depends upon a number of parameters such as its configuration, type of substrate, its concentration, microorganism used, catalyst, materials used in cathode and anode, suitable membrane, which play an important role in its performance (Logan and Regan 2006a, b). Many reports are available of scaling up of MFC from few ml to several thousand liters. The results of these studies have demonstrated that a major drawback in commercialization of MFC is that scaling up causes decreased power output. These studies have 
Table 3 A comparative analysis of Power and current output obtained with wastes and Xenobiotics

\begin{tabular}{|c|c|c|c|c|}
\hline $\begin{array}{l}\text { S. } \\
\text { No. }\end{array}$ & Xenobiotics/Wastes & Concentration & Current/Power output & Reference \\
\hline 1 & Hexavalent chromium & $80 \mathrm{mg} / \mathrm{L}$ & $123.4 \mathrm{~mA} / \mathrm{m}^{2}$ and $55.5 \mathrm{~mW} / \mathrm{m}^{2}$ & Tandukar et al. (2009) \\
\hline 2 & & $39.2 \mathrm{mg} / \mathrm{L}$ & $2.4 \mathrm{~W} / \mathrm{m}^{3}$ & Wang et al. (2008) \\
\hline 3 & & $10 \mathrm{mg} / \mathrm{L}$ & $21.4 \mathrm{~mW} / \mathrm{m}^{2}$ & Gangadharan and Nambi (2015) \\
\hline \multirow[t]{2}{*}{4} & & $100 \mathrm{mg} / \mathrm{L}$ & $767.01 \mathrm{~mW} / \mathrm{m}^{2}$ & Xafenias et al. (2015) \\
\hline & Agrowaste & & & \\
\hline 5 & Cassava waste water & $16000 \mathrm{mg}-\mathrm{COD} / \mathrm{L}$ & $1771 \mathrm{~mW} / \mathrm{m}^{2}$ & Kaewkannetra et al. (2009) \\
\hline 6 & & 1, $086 \mathrm{mg}-\mathrm{COD} / \mathrm{L}$ & $22.19 \mathrm{~W} / \mathrm{m}^{3}$ & Prasertsung et al. (2012) \\
\hline 7 & Cellulose & $1 \mathrm{~g} / \mathrm{LCMC}$ & $143 \mathrm{~mW} / \mathrm{m}^{2}$ & Ren et al. (2008) \\
\hline 8 & & $4 \mathrm{~g} / \mathrm{L}$ & $4.9 \mathrm{~mW} / \mathrm{m}^{2}$ & Rezaei et al. (2009) \\
\hline 9 & & $1 \mathrm{~g} / \mathrm{L}$ & $188 \mathrm{~mW} / \mathrm{m}^{2}$ & Sedky et al. (2012) \\
\hline 10 & Vegetable waste & $0.5 \mathrm{~g}$ COD/L clover sap & $70 \mathrm{~mW} / \mathrm{m}^{3}$ & Clauwaert et al. (2008) \\
\hline 11 & Dioscorea zingiberensis tubers & $3000 \mathrm{mg}-\mathrm{COD} / \mathrm{L}$ & $175 \mathrm{~mW} / \mathrm{m}^{2}$ & Li and Ni (2011) \\
\hline 12 & Brewery waste water & $600 \mathrm{mg}-\mathrm{COD} / \mathrm{L}$ & $830 \mathrm{~mW} / \mathrm{m}^{3}$ & Wen et al. (2010) \\
\hline 13 & Chocolate industry wastewater & 1459 mg/L COD & $0.302 \mathrm{~mA} / \mathrm{cm}^{2}$ & Patil et al. (2009) \\
\hline 14 & Domestic wastewater & $600 \mathrm{mg} / \mathrm{L}$ & $0.06 \mathrm{~mA} / \mathrm{cm}^{2}$ & Wang et al. (2009) \\
\hline 15 & Protein-rich wastewater & $1.75 \mathrm{~g} / \mathrm{L}$ COD & $0.008 \mathrm{~mA} / \mathrm{cm}^{2}$ & Liu et al. (2009b) \\
\hline 16 & Starch processing wastewater & $4852 \mathrm{mg} / \mathrm{L} C O D$ & $0.09 \mathrm{~mA} / \mathrm{cm}^{2}$ & Lu et al. (2009) \\
\hline 17 & Slaughter house waste water & $900 \mathrm{mg}-\mathrm{COD} / \mathrm{L}$ & $578 \mathrm{~mW} / \mathrm{m}^{2}$ & Katuri et al. (2012) \\
\hline 18 & Chicken feathers & $10 \mathrm{~g} / \mathrm{L}$ & $1206.78 \mathrm{~mW} / \mathrm{m}^{2}$ & Chaturvedi et al. (2013) \\
\hline \multirow[t]{2}{*}{19} & Rice straw hydrolysate & $400 \mathrm{mg}-\mathrm{COD} / \mathrm{L}$ & $137.6 \mathrm{~mW} / \mathrm{m}^{2}$ & Wang et al. (2014) \\
\hline & Azo dyes & & & \\
\hline 20 & Acid orange 7 (AO7) & $35 \mathrm{mg} / \mathrm{l}$ & $39.2 \mathrm{~mW} / \mathrm{m}^{2}$ & Fernando et al. (2012) \\
\hline 21 & Azo dye with glucose & $300 \mathrm{mg} / \mathrm{l}$ & $0.09 \mathrm{~mA} / \mathrm{cm}^{2}$ & Sun et al. (2009) \\
\hline 22 & Methyl orange & $0.05 \mathrm{mM}$ & $0.0154 \mathrm{~mA} / \mathrm{cm}^{2}$ & Liu et al. (2009a) \\
\hline 23 & Congo red and glucose & $\begin{array}{l}\text { Congo } \\
\text { red ( } 300 \mathrm{mg} / \mathrm{L}) \text { and glucose }(500 \mathrm{mg} \\
\text { COD/L) }\end{array}$ & $0.0897 \mathrm{~mA} / \mathrm{cm}^{2}$ & Sun et al. (2009) \\
\hline 24 & Reactive blue 221 (RB221) & $112.5 \mathrm{mg} / \mathrm{L}$ & $27.5 \mathrm{~mW} / \mathrm{m}^{2}$ & Bakhshian et al. (2011) \\
\hline 25 & Acid navy blue r (ANB) dye & 200 ppm & $2,236 \mathrm{~mW} / \mathrm{m}^{2}$ & Khan et al. (2015) \\
\hline 26 & Reactive brilliant red X-3B (ABRX3) & $300 \mathrm{mg}-\mathrm{COD} / \mathrm{L}$ & $0.852 \mathrm{~W} / \mathrm{m}^{3}$ & Fang et al. (2015) \\
\hline 27 & Selenium & $25 \mathrm{mg} / \mathrm{L}$ & $2,900 \mathrm{~mW} / \mathrm{m}^{2}$ & Catal et al. (2009) \\
\hline 28 & Nitrate & & $117.7 \mathrm{~mW} / \mathrm{m}^{2}$ & Fang et al. (2011) \\
\hline 29 & & & $502.5 \mathrm{~mW} / \mathrm{m}^{2}$ & Zhang et al. (2014) \\
\hline 30 & & $10.5 \mathrm{mg} / \mathrm{L}$ & $138.31 \mathrm{~mA} / \mathrm{m}^{2}$ & Cai and Zheng (2013) \\
\hline 31 & & $40 \mathrm{mg}-\mathrm{COD} / \mathrm{L}$ & $31.92 \mathrm{~mW} / \mathrm{m}^{2}$ & Cucu et al. (2016) \\
\hline
\end{tabular}

shown that the factor which affects power output in MFC during scaling up is the distance between electrodes. As the size of electrodes is increased during scaling up, the distance between electrodes is not increased to same extent because it will make MFC more bulkier. This is the reason why power output is decreased. Another factor which hinders its scaling up is the cost of electrodes. It should be sufficiently low. However, in reality, the electrodes are very costly because these are not produced industrially and also the material with which they are made is very costly. The membranes used in MFC are usually made up of nylon which is costly. Another important factor is the substrate; in laboratory conditions, when MFC is run on pure substrates the power output is very high but when it is run on waste materials its power output is diminished dramatically. This is due to the fact that microorganisms are not able to metabolize waste materials as efficiently as pure carbon sources. These are the major factors which hinder commercialization of this technology.

\section{Major pit holes of the technology}

MFC being a promising technology for power generation by employing waste material suffers from many challenges which hinder its commercialization. Some of the important pit holes of this technology are as follows: 
1. The power density obtained with xenobiotics and wastes is very low as compared to pure carbon sources such as glucose. This hinders its applicability in waste management and generation of electricity for day to day purposes.

2. Pure carbon sources cannot be routinely employed for electricity generation because they are costly as compared to wastes.

3. The material used in cathode/anode and membrane during scaling up of MFC is costly, which hinders its commercialization.

\section{Future prospects}

MFC is a promising technology for generation of electricity from organic substances, especially from organic waste of different origin. However, there are certain drawbacks, which has hindered to make it more applicable when practical applications are concerned. The major drawback of MFC technology is the low power density; this can be rectified by either isolation of potent microorganisms that can efficiently transfer electrons to anode or by generating engineered strains through recombinant DNA technology that show greater electron transfer rates. Many reports have confirmed that rather than pure cultures, consortium of many bacteria show improved electron transfer rates to the anode. Many bacterial strains have been shown to produce mediators which efficiently transfer electrons to the anode. Identification of new mediators can also increase the performance of MFC technology. Another drawback of MFC is the limited surface area of the electrodes where microorganisms adhere. Extensive studies have been performed to identify methods that enhance the performance of MFC reactors and have resulted in the designing of more efficient laboratory-scale MFCs. These technologies include the use of air cathodes (Liu and Logan 2004), stacked reactors (Aelterman et al. 2006) and cloth electrode assemblies (Fan et al. 2007). Among these, the use of air cathodes (Liu and Logan 2004) is very effective since it helps in efficient use of oxygen from air and avoids the need for aerating the water or using chemical catholytes such as ferricyanide that must be regenerated. Air cathodes have been optimized for the use in MFCs (Cheng et al. 2006a, b), and the effects of shape and position on MFC performances have been evaluated using different reactor designs (Zuo et al. 2007; Fan et al. 2007). These efforts have resulted in highly efficient small-volume laboratory MFCs ( $\sim 20 \mathrm{ml}$ in anode volume) that produced electrical outputs of over $1000 \mathrm{~W} \mathrm{~m}^{3}$ (Fan et al. 2007). However, it is still a challenge for MFC researchers to construct large-scale MFCs that have both high power production and stable performance (Zuo et al. 2007). Liu

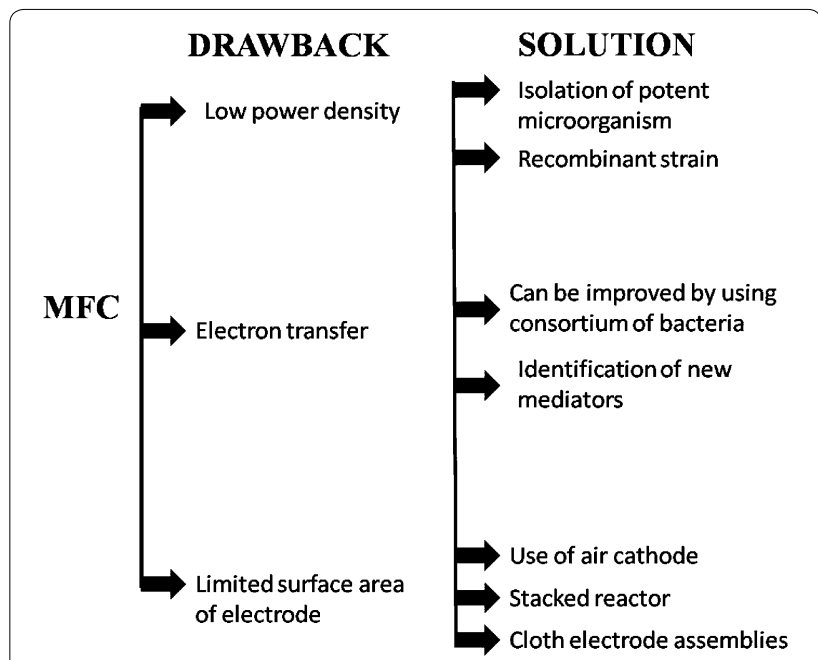

Fig. 4 Outline of various drawbacks of MFC and possible solutions which can help to enhance the efficiency of MFC

et al. (2008) have recently reported the construction of a 500 -ml MFC reactor with the maximum power density of $20 \mathrm{~W} \mathrm{~m}^{3}$ (Fig. 4).

Another drawback of this technology is in treatment of wastewaters and scaling up of MFC. Scaling up of MFCs for large-scale applications and for improving the overall performance of MFC technology will help in treatment of wastewater, which is present in large quantities.

\section{Conclusions}

MFC is a state-of-the-art technology for production of electricity from metabolism of microorganisms. In this review, we have dealt with major wastes and xenobiotics, such as hexavalent chromium, agrowastes, nitrates and azo dyes. Some of them such as hexavalent chromium and azo dyes are very toxic to the ecosystem and cause death of organisms. In MFC, they are used for electricity production and also they are transformed into less toxic metabolites, which demonstrates its another potential use in waste management and pollution control. Till now, a large number of microbes and a waste variety of substrates (including waste and xenobiotics) have been used to produce electricity. However, a major drawback of this technology is that the power output is very low and scaling up leads to a decrease in power output. This is the main reason why this technology has yet not been commercialized. So, a lot more work is required so that this technology becomes efficient, applicable and widely accepted.

\section{Authors' contributions}

PV planned the review. VC carried out the literature survey. PV and VC prepared the MS. Both authors read and approved the final manuscript. 


\begin{abstract}
Author details
${ }^{1}$ School of Biotechnology, Banaras Hindu University, Varanasi 221005, UP, India. ${ }^{2}$ Department of Microbiology, Central University of Rajasthan, N.H. 8 Bandarsindri, Kishangarh, Ajmer 305801, Rajasthan, India.
\end{abstract}

\section{Acknowledgements}

PV is thankful to DBT for providing financial support (Grant No. BT/304/NE/ TBP/2012).

\section{Competing interests}

The authors declare that they have no competing interests.

Received: 30 March 2016 Accepted: 3 August 2016

Published online: 17 August 2016

\section{References}

Aelterman P, Rabaey K, Pham HT, Boon N, Verstraete W (2006) Continuous electricity generation at high voltages and currents using stacked microbial fuel cells. Environ Sci Technol 40:3388-3394

Aldrovandi A, Marsili E, Paganin P, Tabacchioni S, Giordano A (2009) Sustainable power production in a membrane-less and mediator-less synthetic wastewater microbial fuel cell. Biores Technol 100:3252-3260

Allen RM, Bennetto HP (1993) Microbial fuel-cells: electricity production from carbohydrates. Appl Biochem Biotech 39:27-40

Bakhshian S, Kariminia HR, Roshandel R (2011) Bioelectricity generation enhancement in a dual chamber microbial fuel cell under cathodic enzyme catalyzed dye decolorization. Biores Technol 102:6761-6765

Banuelos GS, Lin ZQ (2005) Phytoremediation management of selenium-laden drainage sediments in the San Luis Drain: a greenhouse feasibility study. Ecotoxicol Environ Safety 62(3):309-316

Barkovskii A, Korshunova VE, Pozdnyacova LI (1995) Catabolism of phenol and benzoate by Azospirillum strains. Appl Soil Ecol 2(1):17-24

Behera M, Ghangrekar MM (2009) Performance of microbial fuel cell in response to change in sludge loading rate at different anodic feed $\mathrm{pH}$. Biores Technol 100:5114-5121

Bond DR, Lovley DR (2005) Evidence for involvement of an electron shuttle in electricity generation by Geothrix fermentans. Appl Environ Microbiol 71(4):2186-2189

Cai J, Zheng P (2013) Simultaneous anaerobic sulfide and nitrate removal in microbial fuel cell. Biores Technol 128:760-764

Catal T, Liu H, Bermek H (2008) Selenium induces manganese dependent peroxidase activity by the White-Rot Fungus Bjerkandera adusta (Willdenow) P. Karsten. Biol Trace Elem Res 123(1-3):211-217

Catal T, Bermek H, Liu H (2009) Removal of selenite from wastewater using microbial fuel cells. Biotechnol Lett 31(8):1211-1216

Chae KJ, Choi MJ, Lee JW, Kim KY, Kim IS (2009) Effect of different substrates on the performance, bacterial diversity, and bacterial viability in microbial fuel cells. Biores Technol 100:3518-3525

Chaturvedi V, Verma P (2013) Metabolism of Chicken Feathers and Concomitant Electricity Generation by Pseudomonas aeruginosa by Employing Microbial Fuel Cell (MFC). J Waste Management. doi:10.1155/2013/282798

Chaudhuri SK, Lovley DR (2003) Electricity generation by direct oxidation of glucose in mediatorless-microbial fuel cells. Nat Biotechnol 21(10):1229-1232

Chebotareva N, Nyokong T (1997) Metallophthalocyanine catalysed electroreduction of nitrate and nitrite ions in alkaline media. J Appl Electrochem 27:975-981

Chen YP, Lopez-de-Victoria G, Lovell CR (1993) Utilization of aromatic compounds as carbon and energy sources during growth and N2-fixation by free-living nitrogen fixing bacteria. Arch Microbiol 159(3):207-212

Chen B, Wang Y, Ng I (2010) Understanding interactive characteristics of bioelectricity generation and reductive decolorization using Proteus hauseri. Biores Technol 101(2):4737-4741

Cheng S, Liu H, Logan BE (2006a) Increased power and coulombic efficiency of single-chamber microbial fuel cells through an improved cathode structure. Electrochem Comm 8:489-494
Cheng S, Liu H, Logan BE (2006b) Power densities using different cathode catalysts (Pt and CoTMPP) and polymer binders (Nafion and PTFE) in single-chamber microbial fuel cells. Environ Sci Technol 40:364-369

Choi J, Chang HN, Han JI (2011) Performance of microbial fuel cell with volatile fatty acids from food wastes. Biotechnol Lett 33:705-714

Clauwaert P, Van Der Ha D, Boon N, Verbeken K, Verhaege M, Rabaey K, Verstraete W (2007) An open air biocathode enables effective electricity generation with microbial fuel cells. Environ Sci Technol 41:7564-7569

Clauwaert P, van der Ha D, Verstraete W (2008) Energy recovery from energy rich vegetable products with microbial fuel cells. Biotechnol Lett 30(11):1947-1951

Cucu A, Tiliakos A, Tanase I, Serban CE, Stamatin I, Ciocanea A, Nichita C (2016) Microbial fuel cell for nitrate reduction. Energy Procedia 85:156-161

Daniel DK, Mankidy BD, Ambarish K, Manogari R (2009) Construction and operation of a microbial fuel cell for electricity generation from wastewater. Int J Hydrogen Energy 34:7555-7560

Della Rocca C (2005) Cotton-supported heterotrophic denitrification of nitrate-rich drinking water with a sand filtration post-treatment. Water Res Com 31:229-235

Dima GE, Beltramo GL, Koper MTM (2005) Nitrate reduction on single-crystal platinum electrodes. Electrochim Acta 50:4318-4326

Dos Santos AB, Cervantes FJ, Van Lier JB (2007) Review paper on current technologies for decolourisation of textile wastewaters: perspectives for anaerobic biotechnology. Biores Technol 98(12):2369-2385

Fan Y, Hu H, Liu H (2007) Enhanced columbic efficiency and power density of air-cathode microbial fuel cells with an improved cell configuration. J Power Sources 171:348-354

Fang C, Min B, Angelidaki I (2011) Nitrate as an oxidant in the cathode chamber of a microbial fuel cell for both power generation and nutrient removal purposes. Appl Biochem Biotechnol 164:464-474

Fang Z, Song H, Cang N, Li X (2015) Electricity production from azo dye wastewater using a microbial fuel cell coupled constructed wetland operating under different operating conditions. Biosens Bioelectron 68:135-141

Feng YJ, Wang X, Logan BE, Lee H (2008) Brewery wastewater treatment using air-cathode microbial fuel cells. Appl Microbiol Biotechnol 78:873-880

Fernando E, Keshavarz T, Kyazze G (2012) Enhanced bio-decolourisation of acid orange 7 by Shewanella oneidensis through co-metabolism in a microbial fuel cell. Int Biodeterior Biodegrad 72:1-9

Fournier D, Trott S, Hawari J, Spain J (2005) Metabolism of the aliphatic nitramine 4-nitro-2,4-diazabutanal by Methylobacterium sp. strain JS178. Appl Environ Microbiol 71(8):4199-4202

Fujita M, Ike M, Kashiwa M, Hashimoto R, Soda S (2002) Laboratory-scale continuous reactor for soluble selenium removal using selenate-reducing bacterium, Bacillus sp. SF-1. Biotechnol Bioeng 80(7):755-761

Gangadharan P, Nambi IM (2015) Hexavalent chromium reduction and energy recovery by using dual-chambered microbial fuel cell. Water Sci Technol 71(3):353-358. doi:10.2166/wst.2014.524

Gil GC, Chang IS, Kim BH, Kim M, Jang JK, Park HS, Kim HJ (2003) Operationalparameters affecting the performance of a mediator-less microbial fuel cell. Biosens Bioelectron 18(4):327-334

Greenman J, Gálvez A, Giusti L, leropoulos I (2009) Electricity from landfill leachate using microbial fuel cells: comparison with a biological aerated filter. Enzyme Microb Technol 44:112-119

Ha PT, Tae B, Chang IS (2008) Performance and bacterial consortium of microbial fuel cell fed with formate. Energy Fuels 22:164-168

Hamilton SF (2004) Review of selenium toxicity in aquatic food chains. Sci Total Environ 326(1-3):1-31

He Z, Angenent LT (2006) Application of bacterial biocathodes in microbial fuel cells. Electroanalysis 18:2009-2015

He Z, Minteer SD, Angenent LT (2005) Electricity generation from artificial wastewater using an upflow microbial fuel cell. Environ Sci Technol 39:5262-5267

Heilmann J, Logan B (2006) Production of electricity from proteins using a microbial fuel cell. Water Environ Res 78(5):531-537

Holmes DE, Bond DR, Lovley DR (2004a) Electron transfer by Desulfobulbus propionicus to Fe(III) and graphite electrodes. Appl Environ Microbiol 70(2):1234

Holmes DE, Bond DR, O'Neil RA, Reimers CE, Tender LR, Lovley DR (2004b) Microbial communities associated with electrodes harvesting electricity from a variety of aquatic sediments. Microb Ecol 48:178-190 
Humphries AC, Nott KP, Hall LD, Macaskie LE (2004) Continuous removal of $\mathrm{Cr}(\mathrm{VI})$ from aqueous solution catalyzed by palladised biomass of Desulfovibrio vulgaris. Biotechnol Lett 26:1529-1532

Ichihashi O, Hirooka K (2012) Removal and recovery of phosphorus as struvite from swine wastewater using microbial fuel cell. Biores Technol 114:303-307

Jadhav GS, Ghangrekar MM (2009) Performance of microbial fuel cell subjected to variation in $\mathrm{pH}$, temperature, external load and substrate concentration. Biores Technol 100:717-723

Jia YH, Tran HT, Kim DH, Oh SJ, Park DH, Zhang RH, Ahn DH (2008) Simultaneous organics removal and bio-electrochemical denitrification in microbial fuel cells. Bioproc Biosyst Eng 31:315-321

Kaewkannetra P, Imai T, Garcia-Garcia FJ, Chiu TY (2009) Cyanide removal from cassava mill wastewater using Azotobactor vinelandii TISTR 1094 with mixed microorganisms in activated sludge treatment system. J Hazard Mater 172:224-228

Kashiwa M, Nishimoto S, Takahashi K, Ike M, Fujita M (2000) Factors affecting soluble selenium removal by a selenate reducing bacterium Bacillus sp. SF-1. J Biosci Bioeng 89(6):528-533

Katuri KP, Enright AM, O'Flaherty V, Leech D (2012) Microbial analysis of anodic biofilm in a microbial fuel cell using slaughter house wastewater. Bioelectrochemistry. doi:10.1016/j.bioelechem.2011.12.002

Khan M, Abdulateif H, Ismail IM, Sabir S, Khan MZ (2015) Bioelectricity generation and bioremediation of an azo-dye in a microbial fuel cell coupled activated sludge process. PLOS ONE 10(10):e0138448

Kim N, Choi Y, Jung S, Kim S (2000a) Development of microbial fuel cells using Proteus vulgaris. Bull Korean Chem Soc 21(1):44-48

Kim N, Choi Y, Jung S, Kim S (2000b) Effect of initial carbon sources on the performance of microbial fuel cells containing Proteus vulgaris. Biotechnol Bioeng 70(1):109-114

Kim JR, Jung SH, Regan JM, Logan B (2007) Electricity generation and microbial community analysis of alcohol powered microbial fuel cells. Biores Technol 98:2568-2577

Kondaveeti S, Min B (2012) Nitrate reduction with biotic and abiotic cathodes at various cell voltages in bioelectrochemical denitrification system. Bioprocess Biosyst Eng. doi:10.1007/s00449-012-0779-0

Kurniawan TA, Chan GYS, Lo WH, Babel S (2006) Comparisons of low cost adsorbents for treating wastewaters laden with heavy metals. Sci Total Environ 366:409-426

Lemly AD (1997) Ecosystem recovery following selenium contamination in a freshwater reservoir. Ecotoxicol Environ Saf 36(3):275-281

$\mathrm{Li} \mathrm{H,} \mathrm{Ni} \mathrm{J} \mathrm{(2011)} \mathrm{Treatment} \mathrm{of} \mathrm{wastewater} \mathrm{from} \mathrm{Dioscorea} \mathrm{zingiberensis} \mathrm{tubers}$ used for producing steroid hormones in a microbial fuel cell. Bioresour Technol 102(3):2731-2735

Li X, Hu B, Suib S, Lei Y, Li B (2010) Manganese dioxide as a new cathode catalyst in microbial fuel cells. J Power Sources 195:2586-2591

Liu H, Logan BE (2004) Electricity generation using an air-cathode single chamber microbial fuel cell in the presence and absence of a proton exchange membrane. Environ Sci Technol 38:4040-4046

Liu H, Ramnarayanan R, Logan BE (2004) Production of electricity during wastewater treatment using a single chamber microbial fuel cell. Environ Sci Technol 38(7):2281-2285

Liu ZD, Lian J, Du ZW, Li HR (2006) Construction of sugar-based microbial fuel cells by dissimilatory metal reduction bacteria. Chin J Biotech 22:131-137

Liu H, Cheng S, Huang L, Logan BE (2008) Scale-up of membrane free singlechamber microbial fuel cells. J Power Sources 179:274-279

Liu L, Li F, Feng C, Li X (2009a) Microbial fuel cell with an azo-dye-feeding cathode. Appl Microbiol Biotechnol 85:175-183

Liu Z, Liu J, Zhang S, Su Z (2009b) Study of operational performance and electrical response on mediator-less microbial fuel cells fed with carbonand protein-rich substrates. Biochem Eng J 45:185-191

Logan BE (2004) Biologically extracting energy from wastewater: biohydrogen production and microbial fuel cells. Environ Sci Technol 38:160-167

Logan BE, Regan JM (2006a) Electricity-producing bacterial communities in microbial fuel cells. Trends Biotechnol 14(12):512-518

Logan BE, Regan JM (2006b) Microbial fuel cells: challenges and applications. Environ Sci Technol 40:5172-5180

Lovley DR (2011) Powering microbes with electricity: direct electron transfer from electrodes to microbes. Environ Microbiol Rep 3:27-35
Lu N, Zhou SG, Zhuang L, Zhang JT, Ni JR (2009) Electricity generation from starch processing wastewater using microbial fuel cell technology. Biochem Eng J 43:246-251

Luo H, Liu G, Jin S (2009) Phenol degradation in microbial fuel cells. Chem Eng J 147:259-264

Luo Y, Liu G, Zhang R, Zhang C (2010) Power generation from furfural using the microbial fuel cell. J Power Sources 195:190-194

Manohar AK, Mansfeld F (2009) The internal resistance of a microbial fuel cel and its dependence on cell design and operating conditions. Electrochem Acta 54:1664-1670

Menek N, Karaman Y (2005) Polarographic and voltammetric investigation of 8-hydroxy-7-(4-sulfo-1-naphthylazo)-5-quinoline sulfonic acid. Dyes Pigm 67:9-14

Menicucci J, Beyenal H, Marsili E, Veluchamy RA, Demir G, Lewandowski Z (2006) Procedure for determining maximum sustainable power generated by microbial fuel cells. Environ Sci Technol 40:1062-1068

Min B, Logan BE (2004) Continuous electricity generation from domestic wastewater and organic substrates in a flat plate microbial fuel cell. Environ Sci Technol 38(21):5809-5814

Min B, Kim JR, Oh SE, Regan J, Logan B (2005) Electricity generation from swine wastewater using microbial fuel cells. Water Res 39:4961-4968

Mohanakrishna G, Mohan SV, Sarma PN (2010) Utilizing acid-rich effluents of fermentative hydrogen production process as substrate for harnessing bioelectricity: an integrative approach. Int J Hydrogen Energy 35:3440-3449

Molokwane PE, Meli KC, Nkhalambayausi-Chirw EM (2008) Chromium (VI) reduction in activated sludge bacteria exposed to high chromium loading: brits culture (South Africa). Water Res 42:4538-4548

Niessen J, Schröder U, Harnisch F, Scholz F (2005) Gaining electricity from in situ oxidation of hydrogen produced by fermentative cellulose degradation. Lett Appl Microbiol 41:286-290

Niessen J, Harnisch F, Rosenabaum M, Schröder U, Scholz F (2006) Heat treated soil as convenient and versatile source of bacterial communities for microbial electricity generation. Electrochem Commun 8:869-873

Oh S, Logan B (2005) Hydrogen and electricity production from a food processing wastewater using fermentation and microbial fuel cell technologies. Water Res 39:4673-4682

Pandey A, Singh P, lyengar L (2007) Bacterial decolorization and degradation of azo dyes. Int Biodeterior Biodegrad 59(2):73-84

Park J, Yoo Y (2009) Biological nitrate removal in industrial wastewater treatment: which electron donor we can choose. Appl Microbiol Biotechnol 82:415-429

Park HI, Kim DK, Choi YJ, Park D (2005) Nitrate reduction using an electrode as direct electron donor in a biofilm-electrode reactor. Proc Biochem 40:3383-3388

Parot S, Delia ML, Bergel A (2008) Acetate to enhance electrochemical activity of biofilms from garden compost. Electrochim Acta 53:2737-2742

Patil SA, Surakasi VP, Koul S, ljmulwar S, Vivek A, Shouche YS, Kapadnis BP (2009) Electricity generation using chocolate industry wastewater and its treatment in activated sludge based microbial fuel cell and analysis of developed microbial community in the anode chamber. Biores Technol 100:5132-5139

Peters D, Ngai DD (2000) An DT agro-processing wastewater assessment in periurban Hanoi. CIP program report: 451-457

Pham TH, Boon N, Maeyer KD, Höfte M, Rabaey K, Verstraete W (2008) Use of Pseudomonas species producing phenazine-based metabolites in the anodes of microbial fuel cells to improve electricity generation. Appl Microbiol Biotechnol 80:985-993

Pham H, Boon N, Marzorati M, Verstraete W (2009) Enhanced removal of 1,2-dichloroethane by anodophilic microbial consortia. Water Res 43:2936-2946

Polatides C, Kyriacou G (2005) Electrochemical reduction of nitrate ion on various cathodes-reaction kinetics on bronze cathode. J Appl Electrochem 35:421-427

Potter MC (1911) Electrical effects accompanying the decomposition of organic compounds. Proc R Soc Lond B 84:260-276. doi:10.1098/ rspb.1911.0073

Prasertsung N, Reungsang A, Ratanatamskul C (2012) Alkalinity of cassava wastewater ffed in anodic enhance electricity generation by a single chamber microbial fuel cells. Engr J 16(5):17-28 
Quezada BC, Delia ML, Bergel A (2010) Testing various food-industry wastes for electricity production in microbial fuel cell. Biores Technol 101:2748-2754

Rabaey K, Verstrate W (2005) Microbial fuel cells: novel biotechnology for energy generation. Trends Biotechnol 23:291-298

Rabaey K, Lissens G, Siciliano SD, Verstraete W (2003) A microbial biofuel cell capable of converting glucose to electricity at high rate and efficiency. Biotechnol Lett 25:1531-1535

Rabaey K, Boon N, Siciliano SD, Verhaege M, Verstraete W (2004) Biofuel cells select for microbial consortia that self-mediate electron transfer. Appl Environ Microbiol 70(9):5373-5382

Rabaey K, Clauwaert P, Aelterman P, Verstraete W (2005a) Tubular microbial fuel cells for efficient electricity generation. Environ Sci Technol 39(20):8077-8082

Rabaey K, Ossieur W, Verhaege M, Verstraete W (2005b) Continuous microbial fuel cells convert carbohydrates to electricity. Water Sci Technol 52(1-2):515-523

Rabaey K, Van de Somperl K, Magnien L, Boon N, Aelterman P, Caluwaert P, De Schamphelaire L, Pham H, Vermeulen J, Verhaege M, Lens P, Verstraete W (2006) Microbial fuel cells for sulfide removal. Environ Sci Technol 40(17):5218-5224

Ren Z, Steinberg LM, Regan JM (2008) Electricity production and microbial biofilm characterization in cellulose-fed microbial fuel cells. W Sci Technol 58:617-622

Rezaei F, Richard TL, Brennan RA, Logan BE (2007) Substrate-enhanced microbial fuel cells for improved remote power generation from sediment based systems. Environ Sci Technol 41:4053-4058

Rezaei F, Xing D, Wagner R, Regan JM, Richard TL, Logan BE (2009) Simultaneous cellulose degradation and electricity production by Enterobacter cloacae in a microbial fuel cell. Appl Environ Microbiol 75(11):3673-3678

Riedel GF, Ferrier DP, Sanders JG (1991) Uptake of selenium by freshwater phytoplankton. Water Air Soil Pollut 57-58(1):23-30

Ringeisen BR, Henderson E, Wu PK, Pietron J, Ray R, Little B et al (2006) High power density from a miniature microbial fuel cell using Shewanella oneidensis DSP10. Environ Sci Technol 40:2629-2634

Rismani-Yazidi H, Christy AD, Dehority BA, Morrison M, Yu Z, Tuovinen OH (2007) Electricity generation from cellulose by rumen microorganisms in microbial fuel cells. Biotechnol Bioeng 97(6):1398-1407

Rismani-Yazdi H, Carver SM, Christy AD, Tuovinen OH (2008) Cathode limitations in microbial fuel cells: an overview. J Power Sources 180:683-694

Roldán MD, Blasco R, Caballero FJ, Castillo F (1998) Degradation of pnitrophenol by the phototrophic bacterium Rhodobacter capsulatus. Arch Microbiol 169(1):36-42

Rovira M, Gime'nez J, Martı'nez M et al (2008) Sorption of selenium (IV) and selenium (VI) onto natural iron oxides: goethite and hematite. J Hazard Mater 150(2):279-284

Schröder U, Nießen J, Scholz F (2003) A generation of microbial fuel cells with current outputs boosted by more than one order of magnitude. Angew Chem Int Ed 42:2880-2883

Scott K, Murano C (2007) Microbial fuel cells utilizing carbohydrates. J Chem Technol Biotechnol 82:92-100

Sedky H, Hassan A, Kim YS, Oh S (2012) Power generation from cellulose using mixed and pure cultures of cellulose-degrading bacteria in a microbial fuel cell. Enz Microb Technol 51(5):269-273

Song Z, Zhou J, Wang J, Yan B, Du C (2003) Decolorization of azo dyes by Rhodobacter sphaeroides. Biotechnol Lett 25(21):1815-1818

Stams AJM, De Bok FAM, Plugge CM, Van Eekert MHA, Dolfing J, Schraa G (2006) Exocellular electron-transfer in anaerobic microbial communities. Environ Microbiol 8:371-382

Sun J, Hu YY, Bi Z, Cao YQ (2009) Simultaneous decolorization of azo dye and bioelectricity generation using a microfiltration membrane air-cathode single chamber microbial fuel cell. Biores Technol 100:3185-3192

Sun J, Bi Z, Hou B, Cao Y, Hu Y (2011a) Further treatment of decolorization liquid of azo dye coupled with increased power production using microbial fuel cell equipped with an aerobic biocathode. Water Res 45:283-291

Sun J, Hu YY, Hou B (2011b) Electrochemical characteriztion of the bioanode during simultaneous azo dye decolorization and bioelectricity generation in an air-cathode single chambered microbial fuel cell. Electrochim Acta 56(19):6874-6879
Tandukar M, Huber SJ, Onodera T, Pavlostathis SG (2009) Biological chromium(VI) reduction in the cathode of a microbial fuel cell. Environ Sci Technol 43:8159-8165

Ter Heijne A, Hamelers HVM, Buisman CJN (2007) Microbial fuel cell operation with continuous biological ferrous iron oxidation of the catholyte. Environ Sci Technol 41:4130-4134

Till BA, Weathers $\sqcup$, Alvarez PJJ (1998) Fe(0)-supported autotrophic denitrification. Environ Sci Technol 32:634-639

Torres Cl, Brown RK, Parameswaran P. Marcus AK, Wanger G, Gorby YA, Rittmann BE (2009) Selecting anode-respiring bacteria based on anode potential: phylogenetic, electrochemical, and microscopic characterization. Environ Sci Technol 43:9519-9524

Venkata Mohan S, Saravanan R, Veer Raghuvulu S, Mohanakrishna G, Sarma PN (2008) Bioelectricity production from wastewater treatment in dual chambered microbial fuel cell (MFC) using selectively enriched mixed microflora: effect of catholyte. Bioresour Technol 99:596-603

Vet SJ, Rutgers R (2007) From waste to energy: first experimental Bacterial Fuel Cells onboard the International Space Station. Bremen Microgravity Sci Technol XIX 5(6):225-229

Virdis B, Rabaey K, Yuan ZG, Keller J (2008) Microbial fuel cells for simultaneous carbon and nitrogen removal. Water Res 42:3013-3024

Wang G, Huang LP, Zhang YF (2008) Cathodic reduction of hexavalent chromium $[\mathrm{Cr}(\mathrm{VI})]$ coupled with electricity generation in microbial fuel cells. Biotechnol Lett 30:1959-1966

Wang X, Feng Y, Ren N, Wang H, Lee H, Li N, Zhao Q (2009) Accelerated startup of two-chambered microbial fuel cells: effect of positive poised potential. Electrochem Acta 54:1109-1114

Wang Z, Lee T, Lim B, Choi C, Park J (2014) Microbial community structures differentiated in a single-chamber air-cathode microbial fuel cell fueled with rice straw hydrolysate. Biotechnol Biofuels 7:9. doi:10.1186/1754-6834-7-9

Wen Q, Wu Y, Cao D, Zhao L, Sun Q (2009) Electricity generation and modeling of microbial fuel cell from continuous beer brewery wastewater. Biores Technol 100:4171-4175

Wen Q, Wu Y, Zhao L, Sun Q, Kon F (2010) Electricity generation and brewery wastewater treatment from sequential anode-cathode microbial fuel cell. J Zhejiang Univ Sci B 11(2):87-93

Xafenias N, Zhang Y, Banks CJ (2015) Evaluating hexavalent chromium reduction and electricity production in microbial fuel cells with alkaline cathodes. Int J Env Sci Technol 12(8):2435-2446

Xu MY, Guo J, Sun GP (2007) Biodegradation of textile azo dye by Shewanella decolorationis S12 under microaerophilic conditions. Appl Microbiol Biotechnol 76:719-726

You S, Zhao Q, Zhang J, Jiang J, Zhao S (2006) A microbial fuel cell using permanganate as the cathodic electron-acceptor. J Power Sources 162:1409-1415

You SJ, Ren NQ, Zhao QL, Wang JY, Yang FL (2009) Power generation and electrochemical analysis of biocathode microbial fuel cell using graphite fibre brush as cathode material. Fuel Cells 5:588-596

Zang GL, Sheng GP, Tong ZH, Liu XW, Teng SX, Li WW (2010) Direct electricity recovery from Canna indica by an air-cathode microbial fuel cell inoculated with rumen microorganisms. Env Sci Tech 44:2715-2720

Zhang B, Liu Y, Tong S, Zheng M, Zhao Y, Tian C, Liu H, Feng C (2014) Enhancement of bacterial denitrification for nitrate removal in groundwater with electrical stimulation from microbial fuel cells. J Power Sources 268:423-429

Zheng X, Nirmalakhandan N (2010) Cattle wastes as substrates for bioelectricity production via microbial fuel cells. Biotechnol Lett 32:1809-1814

Zuo Y, Maness P, Logan B (2006) Electricity production from steam-exploded corn stover biomass. Energ Fuel 20:1716-1721

Zuo Y, Cheng S, Call D, Logan BE (2007) Tubular membrane cathodes for scalable power generation in microbial fuel cells. Environ Sci Technol 41:3347-3353 